\title{
DIVERSITY OF CELLULOLYTIC BACTERIA ISOLATED FROM A FRESHWATER WETLAND RESERVE IN THAILAND AND THEIR CELLULOLYTIC ACTIVITY
}

\author{
CHANTARASIRI, A. \\ Faculty of Science, Energy and Environment, King Mongkut's University of Technology North \\ Bangkok, Rayong Campus, Rayong 21120, Thailand \\ e-mail: aiya.c@sciee.kmutnb.ac.th; phone: +66-(0)38-627-000 \#5446
}

(Received 10 $0^{\text {th }}$ Apr 2020; accepted $10^{\text {th }}$ Jul 2020)

\begin{abstract}
Freshwater wetlands are unique aquatic ecosystems, which are a tremendous source of organic carbon. A bacterial community plays a significant role in the carbon cycle of organic matter through its cellulolytic enzymes; namely, cellulases. For this study, culturable bacteria were isolated from a freshwater wetland reserve situated in Thailand and screened for their cellulase production. Seventy-six cellulolytic bacteria were grouped by a PCR-RFLP of $16 \mathrm{~S}$ rDNA technique and identified by a nucleotide sequencing analysis. A total of 17 different RFLP patterns were obtained, belonging to nine bacterial genera including Acinetobacter, Aeromonas, Bacillus, Chromobacterium, Citrobacter, Enterobacter, Herbaspirillum, Paenibacillus and Vibrio. The predominant genera of the isolated cellulolytic bacteria were Bacillus, Chromobacterium and Herbaspirillum. The cellulolytic bacterium isolated from the moist peat samples designated as B. megaterium strain S0702 could produce three types of cellulases and showed the highest CMCase activity at $4.48 \pm 0.08 \mathrm{U} / \mathrm{mL}$. The optimum $\mathrm{pH}$ and temperature for the CMCase activity were determined to be $45-50^{\circ} \mathrm{C}$ at a pH of 7.0 with a stability range of $25-60^{\circ} \mathrm{C}$ and $\mathrm{pH} 5.0$ - 8.0. The CMCase activity was greatly enhanced by $\mathrm{Mn}^{2+}$ and considerably inhibited by EDTA and ethyl-acetate. This enzyme could possibly be used in various biotechnological applications.
\end{abstract}

Keywords: aquatic ecosystem, B. megaterium, cellulase, CMCase activity, PCR-RFLP

\section{Introduction}

Wetlands are natural or artificial, permanent or temporary areas with static or flowing water, where the depth at low tide does not exceed six meters; these include, fens, marshes, peatlands, freshwater areas and marine water areas (Bassi et al., 2014; Kalita et al., 2019). Wetlands serve as a source of biogeochemical cycles, bioremediation of contaminants, flood alleviation and production of food (Leff, 2009). Freshwater wetland is a type of saturated land, the nature of which varies based on the hydrological and plant communities. This unique nature affects the microbial communities dwelling in the wetland. Wetland soils and sediments are also a tremendous source of terrestrial carbon including decayed plants and woody organic matter (Gorham, 1991; An et al., 2019). Microbial communities also play a critical role in the detritus decomposition resulting in dissolved organic carbon and related organic compounds which maintain the nutrient cycle and wetland stableness. Cellulolytic microbes mainly provide the decomposition of cellulose-based plant litter through their cellulolytic enzymes producing the simple sugar derivatives in the sediment (Soares-Júnior et al., 2013). Microbial cellulolytic enzymes, generally called cellulase, are complex substances that comprise endoglucanases (E.C. 3.2.1.4), exoglucanases (E.C. 3.2.1.91, and E.C. 3.2.1.176) and $\beta$-glucosidases (E.C. 3.2.1.21), which synergistically work to hydrolyze the $\beta-1,4$ glycosidic linkages of cellulose polymer (Chantarasiri, 2015). Cellulases account for $20 \%$ of the world enzyme market and have biotechnological promise in various industries; such as, agriculture, animal feed, biofuel, breweries, food, laundry, paper and pulp, pharmaceuticals, textiles 
and waste management (Juturu and $\mathrm{Wu}, 2014$; Behera et al., 2017). Furthermore, microbial cellulases have been reported in aerobic and anaerobic, mesophilic and thermophilic bacteria and fungi (Sharma and Yazdani, 2016). Cellulolytic microbes have been commonly isolated from soil, decaying organic matter, animal digestive tracts and herbivore dung (Juturu and Wu, 2014); such as, Aspergillus (Nwodo-Chinedu et al., 2005; Gao et al., 2008), Bacillus (Anand et al., 2010; Chantarasiri, 2014, 2015; Sriariyanun et al., 2016), Cellulomonas (Sangkharak et al., 2011), Clostridium (Reddy et al., 2010), Fusarium (Qin et al., 2010; Nwodo-Chinedu et al., 2005), Geobacillus (Ibrahim and Eldiwany, 2007; Baharuddin et al., 2010), Gluconacetobacter (Wee et al., 2011) and Penicillium (Nwodo-Chinedu et al., 2005). Currently, most commercial cellulases in the global enzyme market have been produced by Trichoderma reesei and Aspergillus sp. (Zhang et al., 2006). Moreover, a few cellulolytic microbes have been isolated from freshwater wetlands and related environments due to their complexity and inaccessibility. The isolated cellulolytic microbes from freshwater wetlands were identified as bacteria belonging to the genera Bacillus (Chantarasiri et al., 2015), Brucella (Behera et al., 2016), Nocardia (Benhadj et al., 2019), Micromonospora (Benhadj et al., 2019) and fungi belonging to the genera Fusarium, Peziza, and Zygomycete (Wu et al., 2015). The search for cellulolytic microbes still has much interest, and microbial species and environmental sources of microbial isolation have been reported. However, only a few microbes can produce high cellulolytic activity, and only a few can produce all three cellulase enzymes (Sharma and Yazdani, 2016). To improve the knowledge of cellulolytic microbes and their cellulolytic performance, more research has been conducted. Isolation and screening of cellulase-producing microbes from nature is one of the important ways to obtain novel and effective cellulases.

However, sufficient data of cellulolytic microbes isolated from freshwater wetland ecosystem are required. This research consequently aimed to isolate and screen cellulolytic bacteria from Bueng Samnak Yai, a wetland reserve of Thailand. The molecular genetic methods, polymerase chain reaction-restriction fragment length polymorphism (PCR-RFLP) of 16S rDNA and nucleotide sequencing analysis, were used to describe the diversity of a cellulolytic bacterial community. All representative bacteria of each RFLP pattern were determined for their cellulolytic performance. Finally, the most effective bacterium, B. megaterium strain S0702, was cellulolytic characterized to evaluate its biotechnological potential.

\section{Materials and Methods}

\section{Description of the sampling site}

The study area in this research was Bueng Samnak Yai $\left(12^{\circ} 39^{\prime} \mathrm{N}, 101^{\circ} 32^{\prime} \mathrm{E}\right)$ in Rayong province, Thailand. Bueng Samnak Yai has been designated as a wetland reserve, which uniquely combines coastal (brackish) wetland and freshwater wetland. The coastal wetland area is grown over by many characteristic plants (Chantarasiri et al., 2017) which those species are similar to those of a freshwater wetland area. Water and moist peat (partially decayed plants) samples were randomly collected from the grass islands floating in the freshwater wetland area. Twenty water samples and 30 moist peat samples were taken at a depth of $0-5 \mathrm{~cm}$ from the sampling grass islands. The sampling site covered an area of 190 ha with an average depth of water of one meter. The site comprised more than 100 floating and flowing grass islands, which their dimensions ranged from a table-sized to a soccer field-sized island. The grass islands were strongly formed by stem 
and rhizome networks of three dominant grass species consisting of Lepironia articulate (Retz.) Domin, Imperata cylindrica (L.) Beauv. and Carex baccans Nees. All samples were collected during September 2017. The samples were kept at $4^{\circ} \mathrm{C}$ in sterilized plastic bags and taken for bacterial isolation within 24 hours of collection. The locations of the sampling site are shown in Figure 1.

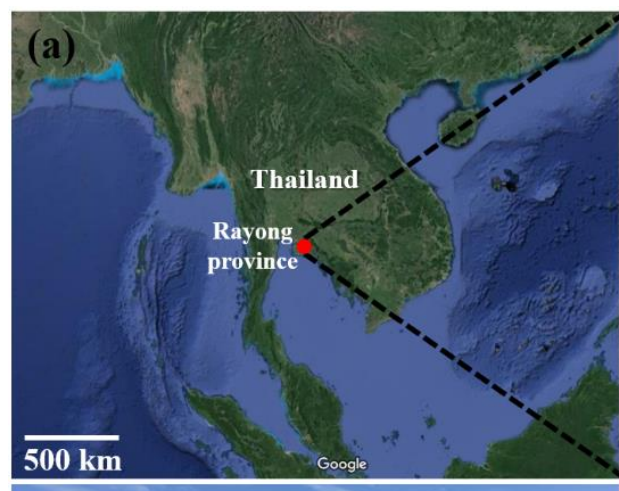

(b)

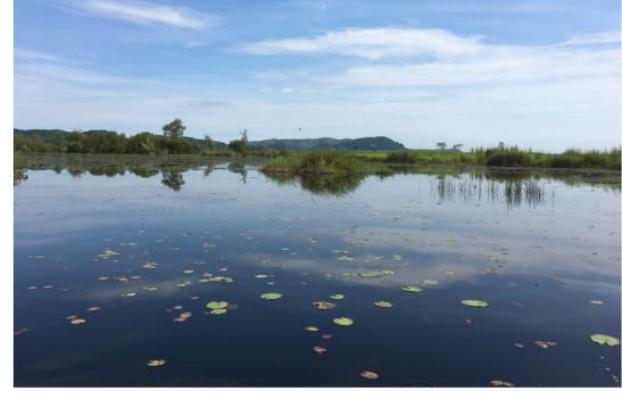

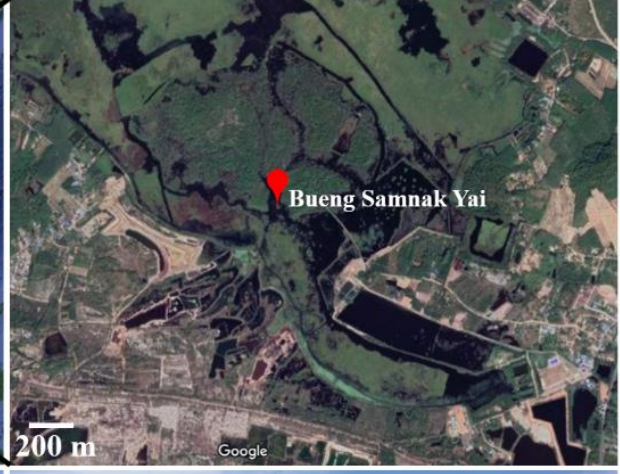

(c)

Figure 1. Bueng Samnak Yai: (a) Map of Bueng Samnak Yai $\left(12^{\circ} 39^{\prime} \mathrm{N}, 101^{\circ} 32^{\prime}\right.$ E) situated in Rayong province, Thailand (Source: Google Maps). (b) Freshwater wetland area and a few table-sized floating grass islands. (c) A scene of a soccer field-sized floating grass island

\section{Isolation and purification of bacteria from the freshwater wetland samples}

Water and moist peat samples were serially diluted with sterilized $0.85 \% \mathrm{NaCl}$ solution supplemented with $0.1 \%$ buffered peptone to obtain 1:10,000 dilutions (Merck, India). One hundred microliters of diluted samples were spread plated on Tryptone soya agar (HiMedia, India) and incubated at $28.5 \pm 0.1^{\circ} \mathrm{C}$ (the average temperature of the sampling site) for 24 hours. The bacterial strains were selected based on the colony's morphology and subsequently the colony was purified by being streak plated on Tryptone soya agar.

\section{Screening of cellulolytic bacteria}

The screening of cellulolytic bacteria from an aquatic environment was conducted from that previously described (Chantarasiri, 2015). One drop (five microliters) of overnight growth culture in the Tryptone soya broth (HiMedia, India) of each isolated bacterium was spot plated on carboxymethyl cellulose (CMC) agar $\left(0.2 \% \mathrm{NaNO}_{3}, 0.1 \%\right.$ $\mathrm{K}_{2} \mathrm{HPO}_{4}, 0.05 \% \mathrm{MgSO}_{4}, 0.05 \% \mathrm{KCl}, 0.2 \% \mathrm{CMC}$ sodium salt, $0.02 \%$ peptone and $1.7 \%$ agar). All culture plates were incubated at $28.5 \pm 0.1^{\circ} \mathrm{C}$ for 48 hours and then flooded 
with iodine solution $\left(0.33 \% \mathrm{I}_{2}\right.$ and $\left.0.67 \% \mathrm{KI}\right)$ for 10 minutes. The bacterial isolates could produce the cellulolytic zone around the colonies after Gram's iodine staining indicated the synthesis of the extracellular cellulases by the cellulolytic candidates. The cellulolytic performance was evaluated by the hydrolysis capacity (HC) value that was calculated from the ratio between the diameter of the cellulolytic zone and the diameter of the bacterial colony. All experiments were performed in triplicate.

\section{Polymerase chain reaction-restriction fragment length polymorphism (PCR-RFLP) of $16 S \mathrm{rDNA}$}

Genomic DNA of each cellulolytic bacteria was extracted by a heat treatment method (Dashti et al., 2009). Polymerase chain reaction (PCR) amplification of the 16S rRNA genes was performed using the OnePCR ${ }^{\mathrm{TM}}$ reaction mixture (Bio-Helix, Taiwan). The primer set used for the amplification of the target $16 \mathrm{~S}$ rRNA genes included the universal forward primer 27F (5'-AGAGTTTGATCMTGGCTCAG-3') and the universal reverse primer 1492R (5'-TACGGYTACCTTGTTACGACTT-3') (Sigma-Aldrich, Singapore). The PCR conditions involved a preheating step at $94^{\circ} \mathrm{C}$ for four minutes, denaturation step at $94^{\circ} \mathrm{C}$ for 40 seconds, annealing step at $55^{\circ} \mathrm{C}$ for one minute, extension step at $72^{\circ} \mathrm{C}$ for 1 minute 10 seconds, and final extension step at $72^{\circ} \mathrm{C}$ for 10 minutes. PCR was performed for 35 amplification cycles in a Mastercycler ${ }^{\circledR}$ Nexus (Eppendorf, Germany). The 16S rDNA fragments resulting from the PCR processes were approximately $1,500 \mathrm{bp}$. The restriction fragment length polymorphism (RFLP) analysis was performed by two restriction enzymes of $M s p \mathrm{I}$ and $A l u \mathrm{I}$ (New England Biolabs, UK) in a CutSmart ${ }^{\circledR}$ buffer (New England Biolabs, UK). The 16S rDNA fragments were digested with MspI and $A l u \mathrm{I}$ at $37^{\circ} \mathrm{C}$ for 12 hours then the digestion reaction was terminated by heating the reaction mixtures at $80^{\circ} \mathrm{C}$ for 15 minutes following the protocol described by New England Biolabs with minor modifications. The resulting restriction fragments were analyzed using 3\% (w/v) OmniPur ${ }^{\circledR}$ agarose gel (Calbiochem, Germany) and visualized by Novel Juice (Bio-Helix, Taiwan). The PCR marker used in this study was a $100 \mathrm{bp}$ DNA ladder RTU (Bio-Helix, Taiwan).

\section{S rDNA sequencing and phylogenetic analysis}

The 16S rDNA PCR products were purified and sequenced by the nucleotide sequencing service of Macrogen Inc. (Seoul, Korea). The sequence similarity analysis of the resulting 16S rDNA was aligned using the BLASTn suite (National Center for Biotechnology Information: NCBI). The phylogenetic tree was analyzed and visualized by the SeaView software version 4.6.4 (Gouy et al., 2010) and FigTree software version 1.4.3 (Institute of Evolutionary Biology, University of Edinburgh, UK). The phylogenetic tree was generated by the neighbor-joining (NJ) method with 100,000 bootstrap replications. All the resulting nucleotide sequences of the identified cellulolytic bacteria from this study were deposited in the GenBank database of NCBI under the accession numbers MN993647, MN993849, MN993893, MN993916, MN994046, MN994069, MN994075, MN994076, MN994079 to MN994082, MN994084 and MN994270 to MN994273.

\section{Preparation of the crude cellulases}

The cellulolytic bacteria were cultured in a CMC liquid medium. All bacterial cultures were shaken under an aeration condition in a baffled flask (Schott-Duran, Germany) at 
$150 \mathrm{rpm}, 28.5 \pm 0.1^{\circ} \mathrm{C}$, for 48 hours. The bacterial cells were then removed from the liquid medium to obtain the crude cellulases by a centrifugation method at 4,500 $\times g$ at $4^{\circ} \mathrm{C}$ for 30 minutes (Chantarasiri, 2015). The crude cellulases were concentrated by 30-kDa Amicon ${ }^{\circledR}$ ultra centrifugal filter units (Millipore, Ireland).

\section{Cellulolytic activity assays of the crude cellulases}

The cellulolytic activity assays of the crude cellulases were conducted from that previously described (Chantarasiri, 2015). The endoglucanase activity (CMCase) was measured by incubating $0.5 \mathrm{~mL}$ of crude cellulases with $0.5 \mathrm{~mL}$ of $2 \% \mathrm{CMC}$ in an assay buffer at $50^{\circ} \mathrm{C}$ for 30 minutes. The exoglucanase activity (Avicelase) was measured by incubating $0.5 \mathrm{~mL}$ of crude cellulases with $0.5 \mathrm{~mL}$ of $2 \%$ Avicel ${ }^{\circledR} \mathrm{PH}-101$ (SigmaAldrich, Germany) in an assay buffer at $50^{\circ} \mathrm{C}$ for one hour. The reducing sugars liberated from the CMCase and Avicelase reactions were spectrophotometrically determined by a 3,5-dinitrosalicylic acid (DNS) method at $540 \mathrm{~nm}$ (Miller, 1959). The cellulolytic activity values of CMCase and Avicelase were calculated by a glucose standard curve. One unit (U) of CMCase and Avicelase was defined as the amount of enzyme required to release $1 \mu \mathrm{mol}$ of the reducing sugars as glucose equivalents per minute under the assay conditions. The $\beta$-glucosidase activity was measured by incubating $0.5 \mathrm{~mL}$ of crude cellulases with $1 \mathrm{~mL}$ of $0.1 \% p$-nitrophenyl- $\beta$-D-glucopyranoside (Sigma-Aldrich, Germany) in an assay buffer at $50^{\circ} \mathrm{C}$ for one hour. The reaction was terminated by adding $2 \mathrm{~mL}$ of $1 \mathrm{M} \mathrm{Na} \mathrm{CO}_{3}$ solution. The reaction mixture was spectrophotometrically measured at $400 \mathrm{~nm}$. The cellulolytic activity values of $\beta$-glucosidase were calculated by a $p$-nitrophenol standard curve. One unit $(\mathrm{U})$ of $\beta$-glucosidase was defined as the amount of enzyme required to release $1 \mu \mathrm{mol}$ of $p$-nitrophenol per minute under the assay conditions. The assay buffer used in this study was $50 \mathrm{mM}$ sodium phosphate buffer at a $\mathrm{pH}$ 7.0, which its $\mathrm{pH}$ value was conducted from Samira et al. (2011) and Shobharani et al. (2013). All experiments were performed in triplicate.

\section{Characterization of the cellulolytic activity from the most active cellulolytic bacteria}

The characterization of the cellulolytic activity was examined on the crude cellulases produced from the most active endoglucanasic bacterium, B. megaterium strain S0702. The study on the cellulolytic activity was determined based on its CMCase activity. The enzymatic characterization focused on three parameters, which affected the cellulolytic activity consisting of temperature, $\mathrm{pH}$ and some chemical additives. All experiments were performed in triplicate.

\section{Effect of temperature on the cellulolytic activity and thermal stability}

The CMCase activity was measured accordingly as mentioned in the section "Cellulolytic activity assays of the crude cellulases" at temperatures ranging from $25^{\circ} \mathrm{C}$ to $80^{\circ} \mathrm{C}$ in an assay buffer. Thermal stability was examined by pre-incubating the crude enzyme at temperatures ranging from $25^{\circ} \mathrm{C}$ to $80^{\circ} \mathrm{C}$ in an assay buffer for 24 hours, and the relative activity of CMCase was monitored using $2 \%$ CMC sodium salt as a substrate under the mentioned CMCase conditions. The assay buffer used in this study was a $50 \mathrm{mM}$ sodium phosphate buffer at a $\mathrm{pH}$ 7.0. 


\section{Effect of $\mathrm{pH}$ on the cellulolytic activity and $\mathrm{pH}$ stability}

The CMCase activity was measured accordingly as mentioned above in the $\mathrm{pH}$-varied buffers at $50^{\circ} \mathrm{C}$. The assay buffer used in this study was a $50 \mathrm{mM}$ citrate buffer $(\mathrm{pH} 4.0$ 6.0), $50 \mathrm{mM}$ sodium phosphate buffer ( $\mathrm{pH} 6.0$ - 8.0) and $50 \mathrm{mM}$ glycine-NaOH buffer (pH 8.0 - 10.0). The $\mathrm{pH}$ stability was examined by pre-incubating the crude enzyme in the above-mentioned buffer at $50^{\circ} \mathrm{C}$ for 24 hours, and the relative activity of CMCase was monitored using $2 \% \mathrm{CMC}$ sodium salt as a substrate under the mentioned CMCase conditions.

\section{Effect of chemical additives on the cellulolytic activity}

The CMCase activity was measured accordingly as mentioned above. Crude cellulases were pre-incubated with metal ions, a chelating agent and organic solvents. Ten metal ions were used comprising $\mathrm{Ca}^{2+}$ (as $\left.\mathrm{CaCl}_{2}\right), \mathrm{Co}^{2+}\left(\right.$ as $\left.\mathrm{CoCl}_{2}\right), \mathrm{Cu}^{2+}$ (as $\left.\mathrm{CuCl}_{2}\right), \mathrm{Fe}^{2+}$ (as $\mathrm{FeCl}_{2}$ ), $\mathrm{Hg}^{2+}$ (as $\mathrm{HgCl}_{2}$ ), $\mathrm{K}^{+}$(as $\mathrm{KCl}$ ), $\mathrm{Mn}^{2+}$ (as $\mathrm{MnCl}_{2}$ ), $\mathrm{Ni}^{2+}$ (as $\mathrm{NiCl}_{2}$ ), $\mathrm{Pb}^{2+}$ (as $\mathrm{PbCl}_{2}$ ) and $\mathrm{Sr}^{2+}$ (as $\left.\mathrm{SrCl}_{2}\right)$. The chelating agent used in this study was ethylene diamine tetraacetic acid (EDTA) sodium salt. The final concentration of the metal ion and chelating agent solutions was $5 \mathrm{mM}$ following the study of Seo et al. (2013). The relative activity of CMCase was monitored using 2\% CMC sodium salt as a substrate after being incubated with the metal ions and chelating agent at $50^{\circ} \mathrm{C}$ for one hour (Annamalai et al., 2013). There were six organic solvents used comprising acetone, dichloromethane, ethanol, ethyl-acetate, methanol and $n$-hexane with the final concentration of $25 \%$ of various organic solvents. The relative activity of CMCase was monitored using $2 \% \mathrm{CMC}$ sodium salt as a substrate after being incubated with the organic solvents at $50^{\circ} \mathrm{C}$ for four hours (Annamalai et al., 2013).

\section{Statistical analysis}

The statistical analysis in this study was analyzed by one-way ANOVA followed by Tukey's test with a 95\% confidence interval using R software version 3.6.2 (R Core Team, 2017).

\section{Results and Discussion}

\section{Description of the freshwater wetland samples}

Twenty water samples and 30 moist peat samples were randomly collected from the sampling site, Bueng Samnak Yai. The average temperature of the 50 sampling points was $28.5 \pm 0.1^{\circ} \mathrm{C}$. All samples were a dark brown color due to the large amount of organic matter and humic substances (Leff, 2009).

\section{Isolation, purification and screening of bacteria from the freshwater wetland samples}

Two-hundred and eight bacterial strains were isolated and purified from the freshwater wetland samples. There were 88 bacterial strains isolated from the water samples and 120 bacterial strains isolated from the moist peat samples with a dissimilar morphological colony. Most aquatic bacteria had a yellow pigmentation, circular shape, entire margin and convex elevation, whereas the moist peat bacteria usually had a white pigmentation, circular shape, entire margin and raised elevation. The percentage of the morphology of the isolated bacteria from the freshwater wetland samples is shown in Table 1. 
Table 1. Percentage of the morphology of the isolated bacteria from the freshwater wetland samples

\begin{tabular}{c|cc|cc|cc|cc}
\hline Bacteria & \multicolumn{2}{|c|}{$\begin{array}{c}\text { Pigmentation } \\
\text { (Percentage) }\end{array}$} & \multicolumn{2}{c|}{$\begin{array}{c}\text { Shape } \\
\text { (Percentage) }\end{array}$} & \multicolumn{2}{c|}{$\begin{array}{c}\text { Margin } \\
\text { (Percentage) }\end{array}$} & \multicolumn{2}{c}{$\begin{array}{c}\text { Elevation } \\
\text { (Percentage) }\end{array}$} \\
\hline \multirow{3}{*}{ Aquatic Bacteria } & Violet & 11.10 & Circular & 90.00 & Entire & 80.00 & Convex & 34.34 \\
& White & 37.38 & Irregular & 7.78 & Erose & 4.44 & Flat & 32.34 \\
& Yellow & 44.85 & Punctiform & 2.22 & Lobate & 5.56 & Raised & 30.00 \\
& Translucent & 6.67 & Filamentous & - & Undulate & 10.00 & Umbonate & 3.32 \\
& Total & 100.00 & Total & 100.00 & Total & 100.00 & Total & 100.00 \\
\hline \multirow{3}{*}{$\begin{array}{c}\text { Moist Peat } \\
\text { Bacteria }\end{array}$} & Violet & 4.17 & Circular & 95.83 & Entire & 97.50 & Convex & 35.00 \\
& White & 68.33 & Irregular & 2.50 & Erose & - & Flat & 23.33 \\
& Yellow & 19.17 & Punctiform & 1.67 & Lobate & 1.67 & Raised & 40.00 \\
& Translucent & 8.33 & Filamentous & - & Undulate & 0.83 & Umbonate & 1.67 \\
& Total & 100.00 & Total & 100.00 & Total & 100.00 & Total & 100.00 \\
\hline
\end{tabular}

The screening of the cellulolytic bacteria using the CMC agar method showed 22 bacterial strains isolated from the water samples (25\% of the isolated aquatic bacteria) and 54 bacterial strains isolated from the moist peat samples $(45 \%$ of the isolated moist peat bacteria) that were defined as active cellulolytic bacteria. The hydrolysis capacity (HC) values of the aquatic bacteria ranged from 1.54 to 3.54 , while that of the moist peat bacteria ranged from 1.57 to 3.55 . The aquatic bacterium strain W0105 and moist peat bacterium strain $\mathrm{S} 0804$ showed a maximum $\mathrm{HC}$ of $3.54 \pm 0.13$ and $3.55 \pm 0.33$, respectively. The cellulolytic zone around the bacterial colonies on the CMC agar plates after Gram's iodine staining is shown in Figure 2. Chantarasiri et al. (2015) reported that there were 87 bacterial strains (60\% of the isolated bacteria) isolated from the coastal wetland soils of Bueng Samnak Yai defined as cellulolytic bacteria. The bacterium with the highest $\mathrm{HC}$ values of that study was the Bacillus sp. strain BR0302 with a HC value of $4.15 \pm 0.18$. From the hydrolytic performance on the CMC agar plates, it was believed that the cellulolytic bacteria dwelling in the moist peat and related terrestrial samples were more abundant than bacteria dwelling in a water sample.

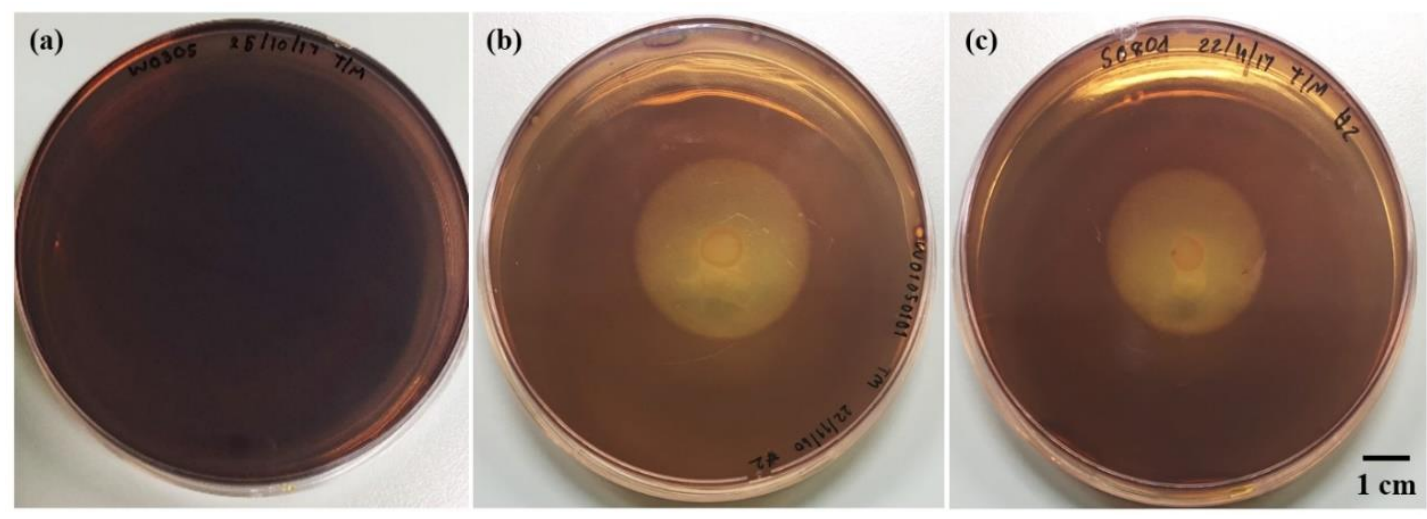

Figure 2. The cellulolytic zone around the colonies on the CMC agar plates after Gram's iodine staining. (a) Non-cellulolytic bacterium. (b) Aquatic-cellulolytic bacterium strain W0105.(c) Moist peat-cellulolytic bacterium strain S0804 


\section{PCR-RFLP analysis of the $16 S$ rDNA fragments amplified from the cellulolytic bacteria}

The 16S rRNA genes of the isolated cellulolytic bacteria were amplified using the PCR method with a set of primers consisting of the 27F-forward primer and 1492R-reverse primer. The 16S rDNA fragments resulting from that amplification were digested by the $M s p \mathrm{I}$ and $A l u \mathrm{I}$ restriction enzymes. The resulting RFLP profiles electrophorized on agarose gel are shown in Figure 3. There were seven different patterns in the RFLP profile obtained from the 22 strains of cellulolytic bacteria isolated from the water samples and 10 different patterns in the profile obtained from the 54 strains of cellulolytic bacteria isolated from the moist peat samples. The different patterns of the RFLP are summarized in Tables 2 and 3. Patterns W1 and W7 were the ones most commonly found in the cellulolytic bacteria isolated from the water samples by 27\%. Pattern W6 showed a smear arrangement; however, there was only one bacterial strain (W1401) in this pattern (Table 2). Therefore, it did not affect the categorization of the pattern and identification of this bacterium. Pattern S4 was the one most commonly found in the cellulolytic bacteria isolated from the moist peat samples by 37\%. All patterns from the moist peat bacteria were explicit arrangements and practicable for bacterial categorization. Interestingly, several patterns of the two RFLP profiles were similar; such as, the pair of patterns W1-S4 (Figure 3). They were possibly believed to be the same species of cellulolytic bacteria like a pair of patterns W2-S5 and a pair of patterns W5-S1 (Figure 3).

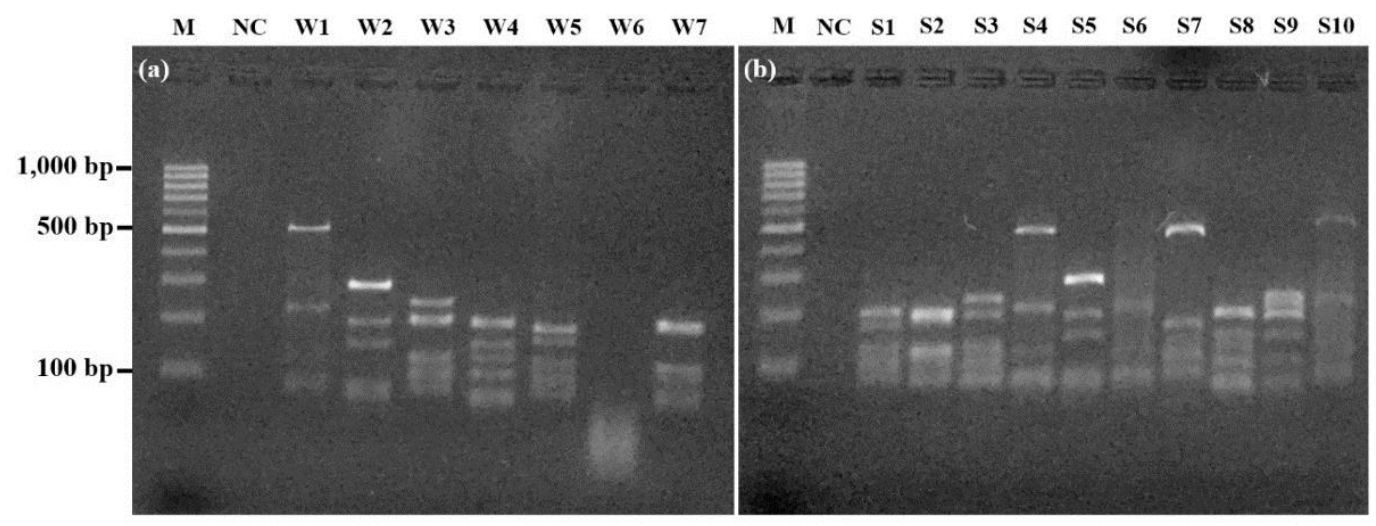

Figure 3. RFLP profiles resulting from the PCR-RFLP analysis of the isolated cellulolytic bacteria. (a) RFLP profile of the cellulolytic bacteria isolated from the water samples (pattern W1 to W7).(b) RFLP profile of the cellulolytic bacteria isolated from the moist peat samples (pattern S1 to S10). M denoted 100 bp DNA ladder RTU. NC denoted negative control of PCR

Table 2. Different RFLP patterns and number of the cellulolytic bacteria isolated from the water samples

\begin{tabular}{c|c|c}
\hline RFLP Pattern & Bacterial Strain & Total No. of Bacterial Strains \\
\hline W1 & W0105, W0902, W1307, W1802, W1902, W2002 & 6 \\
W2 & W0203, W0301, W2003 & 3 \\
W3 & W0303 & 1 \\
W4 & W0306, W2004 & 2 \\
W5 & W0205, W1103, W1504 & 3 \\
W6 & W1401 & 1 \\
W7 & W0903, W1104, W1105, W1506, W1507, W1508 & 6 \\
& Total & 22 \\
\hline
\end{tabular}


Table 3. Different RFLP patterns and number of the cellulolytic bacteria isolated from the moist peat samples

\begin{tabular}{c|c|c}
\hline RFLP Pattern & Bacterial Strain & Total No. of Bacterial Strains \\
\hline S1 & S0104, S0303, S2802 & 3 \\
S2 & S0503 & 1 \\
S3 & S0701, S1202, S2604, S3003 & 4 \\
& S0103, S0201, S0204, S0703, S0804, S0902, S0903, & 20 \\
S4 & S1103, S1302, S1304, S1306, S1702, S2004, S2303, & \\
& S2601, S2605, S2803, S2804, S2904, S3004 & \\
& S0402, S0501, S0601, S0702, S0904, S0905, S0906, & 18 \\
S5 & S0907, S0908, S1601, S1701, S2001, S2902, S2903, & \\
& S2905, S2906, S2907, S3006 & 3 \\
S6 & S1305, S1401, S1404 & 1 \\
S7 & S1402 & 1 \\
S8 & S1602 & 1 \\
S9 & S2606 & 2 \\
S10 & S3007, S3008 & 54 \\
\end{tabular}

\section{Identification of the cellulolytic bacteria by $16 \mathrm{~S}$ rDNA sequencing and phylogenetic analysis}

The genomic DNA was extracted from 17 different bacterial strains based on the RFLP profiles as mentioned above. The $16 \mathrm{~S}$ rDNA amplification was performed by the universal primers, 27F and 1492R. The 16S rDNA PCR-products were purified, sequenced and aligned. The alignment results of the cellulolytic bacteria belonged to nine genera: Acinetobacter, Aeromonas, Bacillus, Chromobacterium, Citrobacter, Enterobacter, Herbaspirillum, Paenibacillus and Vibrio (Table 4). The cellulolytic bacteria isolated from the water samples were closely similar to the bacteria in the genera of Bacillus, Chromobacterium and Enterobacter with a $94-98 \%$ identity. The cellulolytic bacteria isolated from the moist peat samples were closely similar to bacteria in the genera of Acinetobacter, Aeromonas, Bacillus, Chromobacterium, Citrobacter, Herbaspirillum, Paenibacillus and Vibrio with a $93-98 \%$ identity. The moist peat samples had a greater biodiversity of cellulolytic bacteria than the aquatic environment in the freshwater wetland. This could be related to their amount of organic matter and related carbon sources, which would be essential for bacterial life. The phylogenetic tree of the isolated bacteria with 100,000 bootstrap replications is shown in Figure 4.

The cellulolytic bacteria were designated as being closely related based on the alignment results of the $16 \mathrm{~S}$ rDNA sequence when the identity was more than $98 \%$; such as, $B$. wiedmannii strain W1401. The ones which were lower than a $98 \%$ identity were presented at the genus level; such as, Bacillus sp. strain W0105 and Bacillus sp. strain S0804 (the cellulolytic bacteria with the maximum HC values as previously mentioned). The alignment and phylogenetic tree results confirmed the hypothesized identification of the same RFLP patterns as mentioned above comprising patterns W1-S4, W2-S5 and W5S1 (Table 4).

All the 16S rDNA sequences from this study were deposited in the GenBank database of the NCBI under the accession numbers MN993647, MN993849, MN993893, MN993916, MN994046, MN994069, MN994075, MN994076, MN994079 to MN994082, MN994084 and MN994270 to MN994273, as mentioned above in the Materials and Methods section. 
Table 4. Identity percentage of the 16S rDNA sequences for the isolated cellulolytic bacteria

\begin{tabular}{|c|c|c|c|c|}
\hline $\begin{array}{c}\text { RFLP } \\
\text { Pattern }\end{array}$ & Closely Related Bacteria & $\begin{array}{c}\text { GenBank Accession } \\
\text { No. (Database) }\end{array}$ & $\begin{array}{c}\text { Identity } \\
(\%) *\end{array}$ & $\begin{array}{c}\text { GenBank Accession } \\
\text { No. (Deposited) }\end{array}$ \\
\hline W1 & $\begin{array}{c}\text { Bacillus cereus } \\
\text { strain ATCC } 14579\end{array}$ & NR_074540.1 & 94.49 & MN993849 \\
\hline W2 & $\begin{array}{c}\text { Bacillus megaterium } \\
\text { strain ATCC } 14581\end{array}$ & NR_117473.1 & 97.98 & MN993647 \\
\hline W3 & $\begin{array}{l}\text { Chromobacterium piscinae } \\
\text { strain LMG } 3947\end{array}$ & NR_114953.1 & 97.20 & MN993916 \\
\hline W4 & $\begin{array}{c}\text { Enterobacter asburiae } \\
\text { strain JM-458 }\end{array}$ & NR_145647.1 & 96.74 & MN994046 \\
\hline W5 & $\begin{array}{c}\text { Chromobacterium violaceum } \\
\text { strain ATCC } 12472\end{array}$ & NR_074222.1 & 97.55 & MN993893 \\
\hline W6 & $\begin{array}{l}\text { Bacillus wiedmannii } \\
\text { strain FSL W8-0169 }\end{array}$ & NR_152692.1 & 98.83 & MN994075 \\
\hline W7 & $\begin{array}{c}\text { Chromobacterium amazonense } \\
\text { strain CBMAI } 310\end{array}$ & NR_136426.1 & 96.80 & MN994069 \\
\hline $\mathrm{S} 1$ & $\begin{array}{c}\text { Chromobacterium violaceum } \\
\text { strain NBRC } 12614\end{array}$ & NR_113595.1 & 98.25 & MN994079 \\
\hline $\mathrm{S} 2$ & $\begin{array}{l}\text { Chromobacterium vaccinia } \\
\text { strain MWU205 }\end{array}$ & NR_109451.1 & 95.85 & MN994081 \\
\hline S3 & $\begin{array}{l}\text { Herbaspirillum frisingense } \\
\text { strain NBRC } 102522\end{array}$ & NR_114140.1 & 98.61 & MN994082 \\
\hline $\mathrm{S} 4$ & $\begin{array}{c}\text { Bacillus cereus } \\
\text { strain ATCC } 14579\end{array}$ & NR_074540.1 & 95.27 & MN994076 \\
\hline S5 & $\begin{array}{l}\text { Bacillus megaterium } \\
\text { strain ATCC } 14581\end{array}$ & NR_117473.1 & 98.54 & MN994080 \\
\hline S6 & $\begin{array}{l}\text { Aeromonas veronii } \\
\text { strain JCM } 7375\end{array}$ & NR_112838.1 & 93.09 & MN994084 \\
\hline S7 & $\begin{array}{l}\text { Paenibacillus chibensis } \\
\quad \text { strain JCM } 9905\end{array}$ & NR_040885.1 & 97.24 & MN994270 \\
\hline S8 & $\begin{array}{l}\text { Citrobacter koseri } \\
\text { strain CDC-8132-86 }\end{array}$ & NR_104890.1 & 97.43 & MN994271 \\
\hline S9 & $\begin{array}{c}\text { Acinetobacter calcoaceticus } \\
\text { strain NCCB } 22016\end{array}$ & NR_042387.1 & 97.76 & MN994272 \\
\hline S10 & $\begin{array}{c}\text { Vibrio fluvialis } \\
\text { strain NBRC } 103150\end{array}$ & NR_114218.1 & 95.51 & MN994273 \\
\hline
\end{tabular}

Remark: * The identity results were analyzed on January 28, 2020

The predominant bacterial genera of the isolated cellulolytic bacteria in this study were Bacillus of the Firmicutes by $63 \%$, Chromobacterium of the Proteobacteria by $14 \%$, and Herbaspirillum of the Proteobacteria by 5\%. The previous study reported that the bacterial diversity in wetland soils showed predominant bacterial phyla belonging to Proteobacteria, Bacteroidetes, Acidobacteria, Firmicutes and Actinobacteria (Lv et al., 2014). Bacillus is a genus of ubiquitous bacteria frequently isolated from various environments including air, dust, soil, and water. The cellulolytic Bacillus in this study was isolated from both the water and moist peat samples. It was closely related to B. cereus, B. megaterium and B. wiedmannii. Previous reports showed that many Bacillus species were effective cellulolytic bacteria; such as, $B$. cereus, $B$. circulans, B. licheniformis, B. megaterium, B. methylotrophicus and B. subtilis (Chantarasiri, 2014, 2015; Azadian et al., 2016; Shahid et al., 2016). Importantly, this study has now confirmed that the $B$. wiedmannii was cellulolytic bacteria. B. wiedmannii was firstly isolated from a raw milk sample, named, and described in 2016 (Miller et al., 2016). It 
was recently defined as a rice root-associated bacterium and found its cellulase gene by molecular detection in 2020 (Khaskheli et al., 2020). Chromobacterium is a genus of saprophytic bacteria, which are generally isolated from soil and freshwater (Soby et al., 2013). The cellulolytic Chromobacterium was found in both samples similar to the Bacillus species. It was closely related to $C$. amazonense, $C$. piscinae, $C$. vaccinia and C. violaceum. Chromobacterium species have been previously reported as cellulolytic bacteria (Vazquez-Arista et al., 1997; Sudiana et al., 2001). Herbaspirillum is a genus of nitrogen-fixing bacteria associated with the roots of many grasses including rice, maize and sorghum (Kirchhof et al., 2001). H. frisingense was the only species of Herbaspirillum isolated from the moist peat samples. It has been defined as a cellulolytic species described in a previous study (Fujii et al., 2012). The other isolated genera belonging to Acinetobacter, Aeromonas, Citrobacter, Enterobacter, Paenibacillus and Vibrio had been previously reported as cellulolytic bacteria (Gao et al., 2012; Poomai et al., 2014; Pawar et al., 2015; Islam and Roy, 2018; Waghmare et al., 2018).

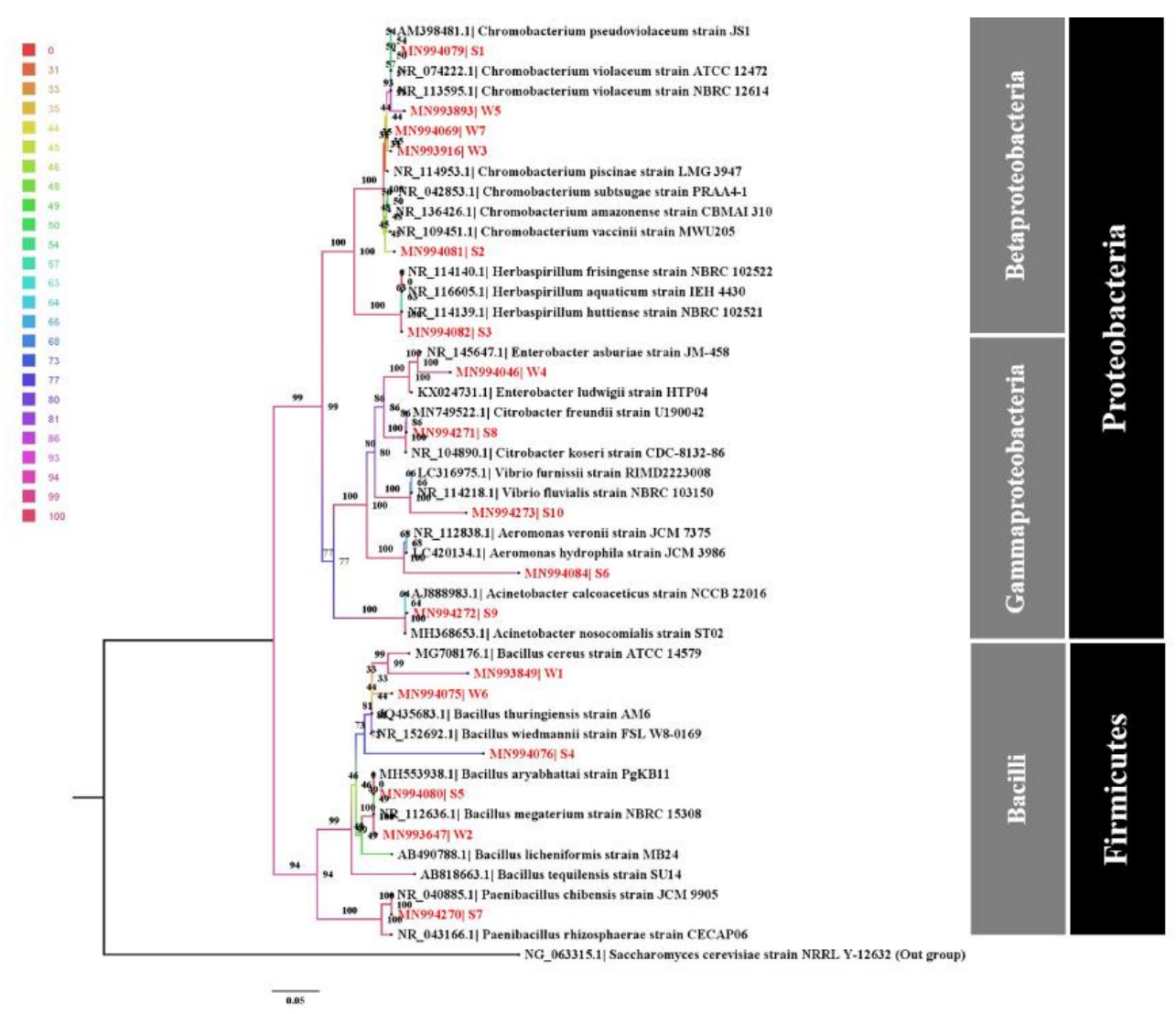

Figure 4. Phylogenetic tree of the $16 \mathrm{~S}$ rDNA sequences of the cellulolytic bacteria. The neighbor-joining (NJ) method with 100,000 bootstrap replications was used in the infer tree topology. The phylogenetic tree was generated and visualized by the SeaView program version 4.6.4 and FigTree program version 1.4.3. The colour-coding represents bootstrap values

\section{Cellulolytic activity assays of the crude cellulases}

The representative bacterium from each RFLP pattern was examined for the cellulolytic activity assays consisting of endoglucanase (CMCase), exoglucanase (Avicelase) and $\beta$-glucosidase activities. The assays showed that they could yield crude 
cellulases from 0.57 to $4.48 \mathrm{U} / \mathrm{mL}$ of the CMCase activity, 0.06 to $0.44 \mathrm{U} / \mathrm{mL}$ of the Avicelase activity and 0.01 to $0.19 \mathrm{U} / \mathrm{mL}$ of the $\beta$-glucosidase activity (Table 5). All representative bacteria satisfactorily produced CMCases; however, they barely produced any Avicelases and $\beta$-glucosidases. It could be stated that endoglucanases were the mainly produced enzyme in their cellulolytic system.

Table 5. Cellulolytic performances of the representative bacteria

\begin{tabular}{|c|c|c|c|c|}
\hline $\begin{array}{l}\text { RFLP } \\
\text { Pattern }\end{array}$ & $\begin{array}{c}\text { Bacterial } \\
\text { Representative }\end{array}$ & $\begin{array}{c}\text { CMCase Activity } \\
\text { (U/mL) with a pH } \\
7.0 \\
\end{array}$ & $\begin{array}{c}\text { Avicelase Activity } \\
\text { (U/mL) with a pH } \\
7.0 \\
\end{array}$ & $\begin{array}{l}\beta \text {-Glucosidase Activity } \\
(\mathrm{U} / \mathrm{mL}) \text { with a pH 7.0 }\end{array}$ \\
\hline W1 & $\begin{array}{l}\text { Bacillus sp. } \\
\text { strain W0105 }\end{array}$ & $3.68 \pm 0.54^{\mathrm{ef}}$ & $0.13 \pm 0.03^{b c}$ & $0.06 \pm 0.01^{\mathrm{bc}}$ \\
\hline W2 & $\begin{array}{l}\text { Bacillus sp. } \\
\text { strain W0301 }\end{array}$ & $3.84 \pm 0.27^{\mathrm{fg}}$ & $0.44 \pm 0.04^{\mathrm{d}}$ & $0.06 \pm 0.01^{\mathrm{bc}}$ \\
\hline W3 & $\begin{array}{c}\text { Chromobacterium sp. } \\
\text { strain W0303 }\end{array}$ & $0.57 \pm 0.02^{\mathrm{a}}$ & $0.07 \pm 0.01^{\mathrm{ab}}$ & $0.02 \pm 0.00^{\mathrm{a}}$ \\
\hline W4 & $\begin{array}{c}\text { Enterobacter sp. } \\
\text { strain W0306 }\end{array}$ & $3.91 \pm 0.08^{\mathrm{fg}}$ & $0.08 \pm 0.03^{\mathrm{ab}}$ & $0.06 \pm 0.01^{\mathrm{bc}}$ \\
\hline W5 & $\begin{array}{l}\text { Chromobacterium sp. } \\
\text { strain W1103 }\end{array}$ & $3.65 \pm 0.17^{\mathrm{ef}}$ & $0.10 \pm 0.03^{\mathrm{ac}}$ & $0.06 \pm 0.00^{\mathrm{bc}}$ \\
\hline W6 & $\begin{array}{c}\text { B. wiedmannii } \\
\text { strain W1401 }\end{array}$ & $3.87 \pm 0.32^{\mathrm{fg}}$ & $0.08 \pm 0.01^{\mathrm{ab}}$ & $0.03 \pm 0.01^{\mathrm{ab}}$ \\
\hline W7 & $\begin{array}{c}\text { Chromobacterium sp. } \\
\text { strain W0903 }\end{array}$ & $1.19 \pm 0.24^{\mathrm{ab}}$ & $0.06 \pm 0.00^{\mathrm{a}}$ & $0.02 \pm 0.00^{\mathrm{a}}$ \\
\hline $\mathrm{S} 1$ & $\begin{array}{l}\text { C. violaceum } \\
\text { strain } \mathrm{S} 2802\end{array}$ & $2.15 \pm 0.17^{\mathrm{cd}}$ & $0.15 \pm 0.03^{c}$ & $0.06 \pm 0.01^{\mathrm{bc}}$ \\
\hline $\mathrm{S} 2$ & $\begin{array}{l}\text { Chromobacterium sp. } \\
\quad \text { strain } \mathrm{S} 0503\end{array}$ & $1.01 \pm 0.10^{\mathrm{a}}$ & $0.07 \pm 0.01^{\mathrm{ab}}$ & $0.02 \pm 0.00^{\mathrm{a}}$ \\
\hline S3 & $\begin{array}{c}\text { H. frisingense } \\
\text { strain S0701 }\end{array}$ & $0.90 \pm 0.07^{\mathrm{a}}$ & $0.08 \pm 0.01^{\mathrm{ab}}$ & $0.02 \pm 0.00^{\mathrm{a}}$ \\
\hline S4 & $\begin{array}{l}\text { Bacillus sp. } \\
\text { strain S0804 }\end{array}$ & $3.17 \pm 0.07^{\mathrm{e}}$ & $0.12 \pm 0.00^{\mathrm{ac}}$ & $0.06 \pm 0.01^{\mathrm{bc}}$ \\
\hline S5 & $\begin{array}{l}\text { B. megaterium } \\
\text { strain S0702 }\end{array}$ & $4.48 \pm 0.08^{g}$ & $0.07 \pm 0.00^{\mathrm{ab}}$ & $0.08 \pm 0.02^{\mathrm{c}}$ \\
\hline S6 & $\begin{array}{l}\text { Aeromonas sp. } \\
\text { strain S1401 }\end{array}$ & $2.21 \pm 0.18^{\mathrm{cd}}$ & $0.08 \pm 0.03^{\mathrm{ab}}$ & $0.06 \pm 0.01^{\mathrm{bc}}$ \\
\hline S7 & $\begin{array}{l}\text { Paenibacillus sp. } \\
\text { strain S1402 }\end{array}$ & $1.73 \pm 0.11^{\mathrm{bc}}$ & $0.08 \pm 0.03^{\mathrm{ab}}$ & $0.07 \pm 0.01^{\mathrm{c}}$ \\
\hline S8 & $\begin{array}{l}\text { Citrobacter sp. } \\
\text { strain S1602 }\end{array}$ & $2.40 \pm 0.29^{\mathrm{d}}$ & $0.10 \pm 0.03^{\mathrm{ac}}$ & $0.08 \pm 0.02^{c}$ \\
\hline S9 & $\begin{array}{l}\text { Acinetobacter sp. } \\
\text { strain S2606 }\end{array}$ & $1.08 \pm 0.17^{\mathrm{a}}$ & $0.07 \pm 0.01^{\mathrm{ab}}$ & $0.01 \pm 0.00^{\mathrm{a}}$ \\
\hline $\mathrm{S} 10$ & $\begin{array}{c}\text { Vibrio sp. } \\
\text { strain S3007 }\end{array}$ & $3.94 \pm 0.07^{\mathrm{fg}}$ & $0.07 \pm 0.00^{\mathrm{a}}$ & $0.19 \pm 0.02^{\mathrm{d}}$ \\
\hline
\end{tabular}

Remark: The mean values in the same row followed by the same letter were not significantly different according to Tukey's test $(p<0.05)$ among the representative bacteria

B. megaterium strain $\mathrm{S} 0702$ was the significant endoglucanasic bacteria at $4.48 \pm 0.08 \mathrm{U} / \mathrm{mL}(p<0.01)$. It was considered as a bacterial model for the following experiments of this study because it was generally considered to be a non-pathogenic and well-known bacterium. Chantarasiri (2015) reported that B. cereus strain JD0404 isolated from mangrove swamp soils was an active endoglucanasic bacterium and primary degraded CMC with its endoglucanase activity. Interestingly, B. megaterium strain S0702 
was not the most active cellulolytic bacterium based on the $\mathrm{HC}$ value determination on the CMC agar. It exhibited only $2.27 \pm 0.17$, which was less than that of Bacillus sp. strains W0105 and S0804. This conflicting result may be due to the fluctuations in some experimental parameters which affected the cellulase producing processes described in several previous reports (Ahmad et al., 2013; Chantarasiri et al., 2015). The cellulolytic activity of B. megaterium strain S0702 was compared to other bacteria in the Bacillus genus isolated from the wetland ecosystems (Table 6). Bacillus sp. strain W0301 significantly produced the high activity of Avicelase by $0.44 \pm 0.04 \mathrm{U} / \mathrm{mL}(p<0.01)$; however, it could not indicate being an effective cellulolytic bacterium due to its medium CMCase and low $\beta$-glucosidase performances. This enzymatic performance was in agreement with the lack of the complete cellulolytic system of the Bacillus genus (Kim et al., 2012). Moreover, Bacillus sp. strain W0301 was closely related to B. cereus that was generally considered as a pathogenic bacterium. Vibrio sp. strain S3007 showed quite a high activity of CMCase and significant $\beta$-glucosidase activity of $0.19 \pm 0.02 \mathrm{U} / \mathrm{mL}$ ( $p<0.01$ ). The Vibrio species could produce $\beta$-glucosidase for utilizing the glucans and related compounds (Wang et al., 2015). However, it was not appropriate for further experiments and industrial applications, as it was believed to be a human-pathogenic bacterium.

Table 6. Cellulolytic performance of B. megaterium strain $S 0702$ and the related bacteria in the Bacillus genus isolated from the wetlands and related environments

\begin{tabular}{|c|c|c|c|c|c|}
\hline Bacteria & $\begin{array}{l}\text { Source of } \\
\text { Isolation }\end{array}$ & $\begin{array}{l}\text { CMCase } \\
\text { Activity } \\
\text { (U/mL) }\end{array}$ & $\begin{array}{c}\text { Avicelase } \\
\text { Activity } \\
\text { (U/mL) } \\
\end{array}$ & $\begin{array}{c}\beta \text {-Glucosidase } \\
\text { Activity } \\
(\mathrm{U} / \mathrm{mL}) \\
\end{array}$ & References \\
\hline $\begin{array}{c}\text { Bacillus sp. } \\
\text { strain BR0302 }\end{array}$ & Coastal wetland & 0.12 & ND & ND & $\begin{array}{c}\text { Chantarasiri et al. } \\
(2015)\end{array}$ \\
\hline $\begin{array}{c}\text { B. cereus } \\
\text { strain JD0404 }\end{array}$ & $\begin{array}{l}\text { Mangrove } \\
\text { swamp }\end{array}$ & 1.78 & 0.08 & 0.05 & $\begin{array}{c}\text { Chantarasiri } \\
\text { (2015) }\end{array}$ \\
\hline $\begin{array}{l}\text { B. licheniformis } \\
\text { strain CDB-12 }\end{array}$ & $\begin{array}{l}\text { Mangrove in a } \\
\text { river delta }\end{array}$ & $98.25 *$ & ND & ND & $\begin{array}{l}\text { Behera et al. } \\
\text { (2016) }\end{array}$ \\
\hline $\begin{array}{c}\text { B. subtilis } \\
\text { strain A-53 }\end{array}$ & Seawater & $92 *$ & ND & ND & Kim et al. (2009) \\
\hline $\begin{array}{l}\text { B. megaterium } \\
\text { strain S0702 }\end{array}$ & $\begin{array}{l}\text { Freshwater } \\
\text { wetland }\end{array}$ & 4.48 & 0.07 & 0.08 & $\begin{array}{l}\text { This current } \\
\text { study. }\end{array}$ \\
\hline
\end{tabular}

Remark: $*$ purified cellulases. ND $=$ not determined

\section{Characterization of the cellulolytic activity from B. megaterium strain $\mathrm{S0702}$}

Crude cellulases from B. megaterium strain S0702 were characterized for the CMCase performance in different experimental conditions; such as, temperature, $\mathrm{pH}$ and chemical additives. The optimum temperature and $\mathrm{pH}$ for the CMCase activity of the crude cellulases were $45-50^{\circ} \mathrm{C}(p<0.01)$ with a pH $7.0(p<0.01)$ (Figures $5 a$ and $\left.6 a\right)$. The enzyme remained stable at up to $60^{\circ} \mathrm{C}(p<0.01)$ and a pH range of $5.0-8.0(p<0.01)$ for 24 hours (Figures $5 b$ and $6 b$ ). The different buffers with the same $\mathrm{pH}$ were not significantly affected by the CMCase activity (Figure $6 b$ ). The cellulases produced from other B. megaterium were studied and evaluated for their CMCase activity. It was found that $B$. megaterium strain BM05 had the optimum $\mathrm{pH}$ and temperature of 6.5 and $50^{\circ} \mathrm{C}$ with a stability range of $6.0-8.0$ and $30-40^{\circ} \mathrm{C}$ (Shahid et al., 2016). The CMCase from B. megaterium strain CB-sw1-I was optimally active with a $\mathrm{pH} 6.0$ and temperature of 
$60^{\circ} \mathrm{C}$ (Shobharani et al., 2013). The CMCases from many Bacillus species were active at a temperature range of $50-60^{\circ} \mathrm{C}$ and a $\mathrm{pH}$ range of 4.8 - 11.0 (Sadhu and Maiti, 2013; Chantarasiri, 2015). This B. megaterium CMCase was preferred for various industrial applications; such as, bioethanol industries and agricultural industries because the enzyme could be active and hydrolyze the cellulose-based materials under mild conditions with a neutral $\mathrm{pH}$ and meso-temperature.
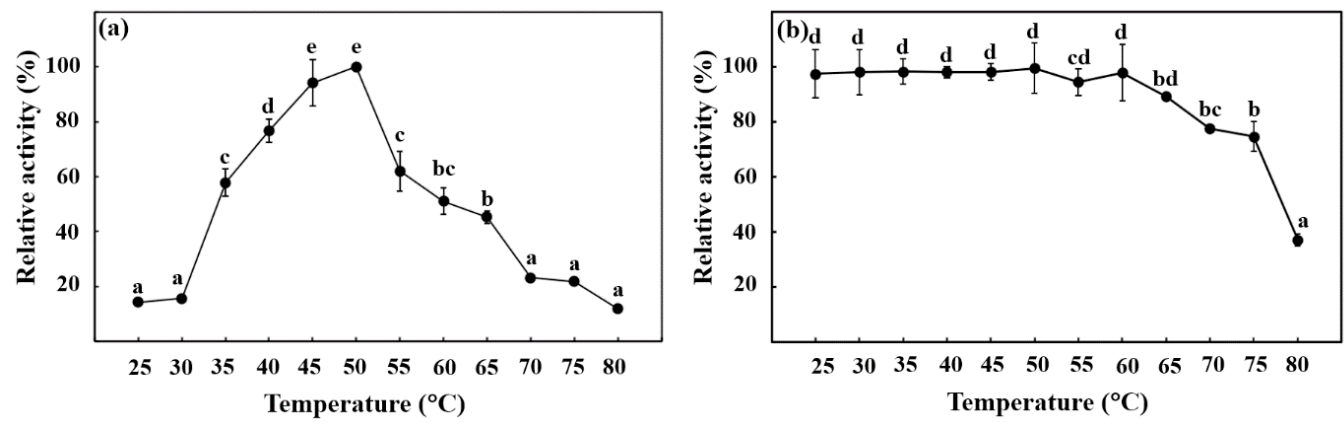

Figure 5. Effect of temperature on the CMCase activity (a) and stability (b) from B. megaterium strain S0702. Error bars represent the standard deviation of the three replicates. The mean values followed by the same letter were not significantly different according to Tukey's test $(p<0.05)$ among the CMCase activity
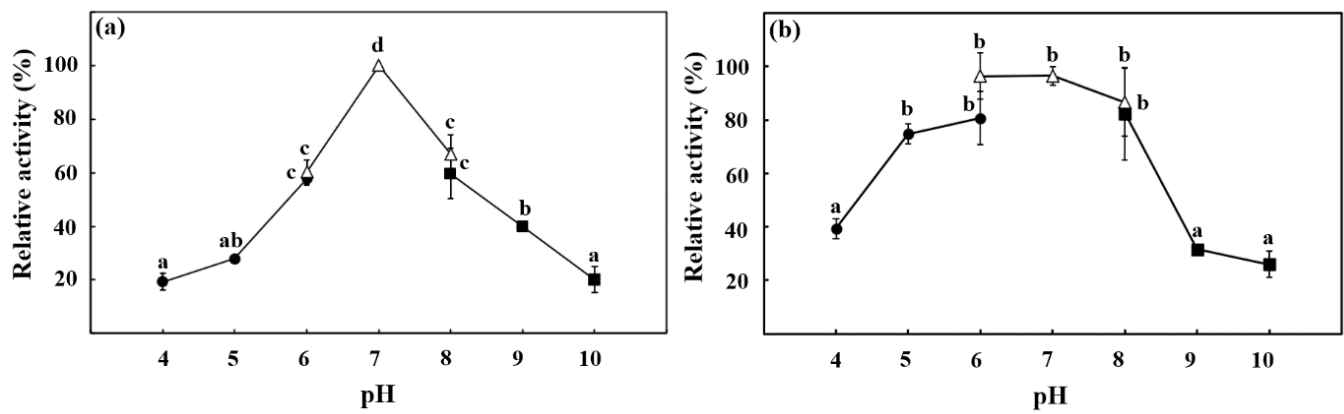

Figure 6. Effect of $p H$ on the CMCase activity $(a)$ and stability $(b)$ from B. megaterium strain S0702. The CMCase activity was measured in a citrate buffer ( $(\mathbf{)}$ ), sodium phosphate buffer $(\triangle)$ and glycine-NaOH buffer $(\boldsymbol{\square})$. Error bars represent the standard deviation of the three replicates. The mean values followed by the same letter were not significantly different according to Tukey's test $(p<0.05)$ among the CMCase activity

The effect of various chemical additives is shown in Table 7. The results of the metal ions revealed that the CMCase activity of $B$. megaterium strain S0702 was significantly enhanced by $\mathrm{Mn}^{2+}, \mathrm{Ca}^{2+}, \mathrm{Co}^{2+}$ and $\mathrm{Sr}^{2+}(p<0.01)$. Similarly, many previous reports showed that these metal ions could activate the CMCase activity of Bacillus cellulases (Shobharani et al., 2013; Chantarasiri, 2015; Shahid et al., 2016). It was believed that they could possibly respond to certain amino acid residues in the active site and promote the favorable conformation of the enzyme to the substrate binding and enzyme activity (Azzeddine et al., 2013; Shahid et al., 2016). $\mathrm{Mn}^{2+}$ could be promised as the great activator of the CMCase in further biotechnological applications due to being less toxic than those of other metal ions. Many $\mathrm{Mn}^{2+}$ compounds were known; such as, manganese 
sulfate $\left(\mathrm{MnSO}_{4}\right)$ and manganese chloride $\left(\mathrm{MnCl}_{2}\right)$. Most metal ions and organic solvents could inhibit the CMCase activity of B. megaterium strain S0702. The activity was significantly inhibited by EDTA and ethyl-acetate. The reduction of the cellulolytic performance by a chelating agent EDTA revealed that the CMCase from B. megaterium strain S0702 could be identified as a metalloenzyme (Annamalai et al., 2013). The results indicated that this CMCase was not remarkably appropriate for any organic solvent related applications.

Table 7. Effect of the various chemical additives on the CMCase activity from B. megaterium strain S0702

\begin{tabular}{c|c}
\hline Chemical Additives & Relative Activity (\%) \\
\hline $\mathrm{Ca}^{2+}$ & $241.25 \pm 7.43^{\mathrm{j}}$ \\
$\mathrm{Co}^{2+}$ & $221.01 \pm 0.78^{\mathrm{i}}$ \\
$\mathrm{Cu}^{2+}$ & $77.51 \pm 7.79^{\mathrm{ef}}$ \\
$\mathrm{Fe}^{2+}$ & $68.06 \pm 5.45^{\mathrm{e}}$ \\
$\mathrm{Hg}^{2+}$ & $64.91 \pm 6.18^{\mathrm{de}}$ \\
$\mathrm{K}^{+}$ & $50.52 \pm 7.79^{\mathrm{cd}}$ \\
$\mathrm{Mn}^{2+}$ & $625.87 \pm 0.78^{\mathrm{k}}$ \\
$\mathrm{Ni}^{2+}$ & $74.81 \pm 2.06^{\mathrm{ef}}$ \\
$\mathrm{Pb}^{2+}$ & $63.56 \pm 1.35^{\mathrm{de}}$ \\
$\mathrm{Sr}^{2+}$ & $199.42 \pm 7.43^{\mathrm{h}}$ \\
$\mathrm{EDTA}^{\mathrm{h}}$ & $23.98 \pm 4.34^{\mathrm{ab}}$ \\
$\mathrm{Acetone}$ & $38.82 \pm 4.43^{\mathrm{bc}}$ \\
Dichloromethane & $68.51 \pm 7.79^{\mathrm{e}}$ \\
Ethanol & $95.05 \pm 2.06^{\mathrm{g}}$ \\
Ethyl-acetate & $22.63 \pm 3.12^{\mathrm{a}}$ \\
Methanol & $63.56 \pm 4.05^{\mathrm{de}}$ \\
$n$-Hexane & $88.30 \pm 0.78^{\mathrm{fg}}$ \\
\hline
\end{tabular}

Remark: The mean values followed by the same letter were not significantly different according to Tukey's test $(p<0.05)$ among the CMCase activity

\section{Conclusion}

The freshwater wetland ecosystem is a potential source for the isolation of cellulolytic bacteria. There were nine genera of cellulolytic bacteria isolated from Bueng Samnak Yai, a freshwater wetland in Thailand based on the RFLP-PCR of a 16S rDNA and nucleotide sequencing analysis comprising Acinetobacter, Aeromonas, Bacillus, Chromobacterium, Citrobacter, Enterobacter, Herbaspirillum, Paenibacillus and Vibrio. The cellulolytic performance of the representative bacteria from each RFLP pattern was determined. It revealed that $B$. megaterium strain S0702 was the most active CMCase bacterium. Its CMCase was characterized and found that it could possibly be used in various biotechnological applications. This CMCase was not remarkably appropriate for some metal ions and organic solvent related applications. Finally, further study on enzyme purification, enzyme kinetic and applications of CMCase are suggested. 


\section{REFERENCES}

[1] Ahmad, B., Nigar, S., Shah, S. S. A., Bashir, S., Ali, J., Yousaf, S., Bangash, J. A. (2013): Isolation and identification of cellulose degrading bacteria from municipal waste and their screening for potential antimicrobial activity. - World Applied Sciences Journal 27: 14201426.

[2] An, J., Liu, C., Wang, Q., Yao, M., Rui, J., Zhang, S., Li, X. (2019): Soil bacterial community structure in Chinese wetlands. - Geoderma 337: 290-299.

[3] Anand, A. A. P., Vennison, S. J., Sankar, S. G., Prabhu, D. I. G., Vasan, P. T., Raghuraman, T., Geoffrey, C. J., Vendan, S. E. (2010): Isolation and characterization of bacteria from the gut of Bombyx mori that degrade cellulose, xylan, pectin and starch and their impact on digestion. - Journal of Insect Science 10: 1-20.

[4] Annamalai, N., Rajeswari, M. V., Elayaraja, S., Balasubramanian, T. (2013): Thermostable, haloalkaline cellulase from Bacillus halodurans CAS 1 by conversion of lignocellulosic wastes. - Carbohydrate Polymers 94: 409-415.

[5] Azadian, F., Badoei-Dalfard, A., Namaki-Shoushtari, A., Hassanshahian, M. (2016): Purification and biochemical properties of a thermostable, haloalkaline cellulase from Bacillus licheniformis AMF-07 and its application for hydrolysis of different cellulosic substrates to bioethanol production. - Molecular Biology Research Communications 5(3): $143-155$.

[6] Azzeddine, B., Abdelaziz, M., Estelle, C., Mouloud, K., Nawel, B., Nabila, B., Francis, D., Said, B. (2013): Optimization and partial characterization of endoglucanase produced by Streptomyces sp. BPNG23. - Archives of Biological Sciences 65(2): 549-558.

[7] Baharuddin, A. S., Razak, M. N. A., Hock, L. S., Ahmad, M. N., Abd-Aziz, S., Rahman, N. A. A., Shah, U. K. M., Hassan, M. A., Sakai, K., Shirai, Y. (2010): Isolation and characterization of thermophilic cellulase-producing bacteria from empty fruit bunchespalm oil mill effluent compost. - American Journal of Applied Sciences 7(1): 56-62.

[8] Bassi, N., Kumar, M. D., Sharma, A., Pardha-Saradhi, P. (2014): Status of wetlands in India: A review of extent, ecosystem benefits, threats and management strategies. - Journal of Hydrology: Regional Studies 2: 1-19.

[9] Behera, B. C., Mishra, R. R., Singh, S. K., Dutta, S. K., Thatoi, H. (2016): Cellulase from Bacillus licheniformis and Brucella sp. isolated from mangrove soils of Mahanadi river delta, Odisha, India. - Biocatalysis and Biotransformation 34(1): 44-53.

[10] Behera, B. C., Sethi, B. K., Mishra, R. R., Dutta, S. K., Thatoi, H. N. (2017): Microbial cellulases-Diversity \& biotechnology with reference to mangrove environment: A review. - Journal of Genetic Engineering and Biotechnology 15: 197-210.

[11] Benhadj, M., Gacemi-Kirane, D., Menasria, T., Guebla, K., Ahmane, Z. (2019): Screening of rare actinomycetes isolated from natural wetland ecosystem (Fetzara Lake, northeastern Algeria) for hydrolytic enzymes and antimicrobial activities. - Journal of King Saud University-Science 31: 706-712.

[12] Chantarasiri, A. (2014): Novel halotolerant cellulolytic Bacillus methylotrophicus RYC01101 isolated from ruminant feces in Thailand and its application for bioethanol production. - KMUTNB: International Journal of Applied Science and Technology 7(3): 63-68.

[13] Chantarasiri, A. (2015): Aquatic Bacillus cereus JD0404 isolated from the muddy sediments of mangrove swamps in Thailand and characterization of its cellulolytic activity. - Egyptian Journal of Aquatic Research 41: 257-264.

[14] Chantarasiri, A., Boontanom, P., Yensaysuk, N., Ajwichai, P. (2015): Isolation and identification of a cellulase-producing Bacillus sp. strain BR0302 from Thai coastal wetland soil. - KMUTNB: International Journal of Applied Science and Technology 8(3): 197-203. 
[15] Chantarasiri, A., Boontanom, P., Nuiplot, N. (2017): Isolation and characterization of Lysinibacillus sphaericus BR2308 from coastal wetland in Thailand for the biodegradation of lignin. - AACL Bioflux 10(2): 200-209.

[16] Dashti, A. A., Jadaon, M. M., Abdulsamad, A. M., Dashti, H. M. (2009): Heat treatment of bacteria: A simple method of DNA extraction for molecular techniques. - Kuwait Medical Journal 41(2): 117-122.

[17] Fujii, K., Ikeda, K., Yoshida, S. (2012): Isolation and characterization of aerobic microorganosms with cellulolytic activity in the gut of endogeic earthworms. International Microbiology 15: 121-130.

[18] Gao, J. H., Weng-Zhu, D., Yuan, M., Guan, F., Xi, Y. (2008): Production and characterization of cellulolytic enzymes from the thermoacidophilic fungal Aspergillus terreus M11 under solid-state cultivation of corn stover. - Bioresource Technology 99: 7623-7629.

[19] Gao, Z. M., Xiao, J., Wang, X. N., Ruan, L. W., Chen, X. L., Zhang, Y. Z. (2012): Vibrio xiamenensis sp. nov., a cellulase-producing bacterium isolated from mangrove soil. International Journal of Systematic and Evolutionary Microbiology 62: 1958-1962.

[20] Gorham, E. (1991): Northern peatlands: role in the carbon cycle and probable responses to climatic warming. - Ecological Applications 1(2): 182-195.

[21] Gouy, M., Guindon, S., Gascuel, O. (2010): SeaView version 4: A multiplatform graphical user interface for sequence alignment and phylogenetic tree building. - Molecular Biology and Evolution 27(2): 221-224.

[22] Ibrahim, A. S. S., El-diwany, A. I. (2007): Isolation and identification of new cellulases producing thermophilic bacteria from an Egyptian hot spring and some properties of the crude enzyme. - Australian Journal of Basic and Applied Sciences 1(4): 473-478.

[23] Islam, F., Roy, N. (2018): Screening, purification and characterization of cellulase from cellulase producing bacteria in molasses. - BMC Research Notes 11(445): 1-6. doi: https://doi.org/10.1186/s13104-018-3558-4.

[24] Juturu, V., Wu, J. C. (2014): Microbial cellulases: Engineering, production and applications. - Renewable and Sustainable Energy Reviews 33: 188-203.

[25] Kalita, S., Sarma, H. P., Devi, A. (2019): Sediment characterisation and spatial distribution of heavy metals in the sediment of a tropical freshwater wetland of Indo-Burmese province. - Environmental Pollution 250: 969-980.

[26] Khaskheli, M. A., Wu, L., Chen, G., Chen, L., Hussain, S., Song, D., Liu, S., Feng, G. (2020): Isolation and characterization of root-associated bacterial endophytes and their biocontrol potential against major fungal phytopathogens of rice (Oryza sativa L.). Pathogens 9(3): 1-28. doi:10.3390/pathogens9030172.

[27] Kim, B. K., Lee, B. H., Lee, Y. J., Jin, I. H., Chung, C. H., Lee, J. W. (2009): Purification and characterization of carboxymethylcellulase isolated from a marine bacterium, Bacillus subtilis subsp. subtilis A-53. - Enzyme and Microbial Technology 44: 411-416.

[28] Kim, Y. K., Lee, S. C., Cho, Y. Y., Oh, H. J., Ko, Y. H. (2012): Isolation of cellulolytic Bacillus subtilis strains from agricultural environments. - International Scholarly Research Notices, doi: https://doi.org/10.5402/2012/650563.

[29] Kirchhof, G., Eckert, B., Stoffels, M., Baldani, J. I., Reis, V. M., Hartmann, A. (2001): Herbaspirillum frisingense sp. nov., a new nitrogen-fixing bacterial species that occurs in C4-fibre plants. - International Journal of Systematic and Evolutionary Microbiology 51: 157-168.

[30] Leff, L. G. (2009): Freshwater Habitats. - In: Schaechter, M. (ed.) Encyclopedia of Microbiology. Elsevier Inc., Amsterdam.

[31] Lv, X., Yu, J., Fu, Y., Ma, B., Qu, F., Ning, K., Wu, H. (2014): Meta-analysis of the bacterial and archaeal diversity observed in wetland soils. - The Scientific World Journal, doi: http://dx.doi.org/10.1155/2014/437684.

[32] Miller, G. (1959): Use of dinitrosalicylic acid reagent for determination of reducing sugar. - Analytical Chemistry 31: 426-428. 
[33] Miller, R. A., Beno, S. M., Kent, D. J., Carroll, L. M., Martin, N. H., Boor, K. J., Kovac, J. (2016): Bacillus wiedmannii sp. nov., a psychrotolerant and cytotoxic Bacillus cereus group species isolated from dairy foods and dairy environments. - International Journal of Systematic and Evolutionary Microbiology 66: 4744-4753.

[34] Nwodo-Chinedu, S., Okochi, V. I., Smith, H. A., Omidij, O. (2005): Isolation of cellulolytic microfungi involved in wood-waste decomposition: prospects for enzymatic hydrolysis of cellulosic wastes. - International Journal of Biomedical and Health Sciences 1: 41-52.

[35] Pawar, K. D., Dar, M. A., Rajput, B. P., Kulkarni, G. J. (2015): Enrichment and identification of cellulolytic bacteria from the gastrointestinal tract of Giant African snail, Achatina fulica. - Applied Biochemistry and Biotechnology 175(4): 1971-1980.

[36] Poomai, N., Siripornadulsil, W., Siripornadulsil, S. (2014): Cellulase enzyme production from agricultural waste by Acinetobacter sp. KKU44. - Advanced Materials Research 931932: 1106-1110.

[37] Qin, Y., He, H., Li, N., Ling, M., Liang, Z. (2010): Isolation and characterization of a thermostable cellulase-producing Fusarium chlamydosporum. - World Journal of Microbiology and Biotechnology 26: 1991-1997.

[38] R Core Team (2017): R: A language and environment for statistical computing. - R Foundation for Statistical Computing, Vienna, Austria. URL https://www.R-project.org/.

[39] Reddy, H. K., Srijana, M., Reddy, M. D., Reddy, G. (2010): Coculture fermentation of banana agro-waste to ethanol by cellulolytic thermophilic Clostridium thermocellum CT2. - African Journal of Biotechnology 9: 1926-1934.

[40] Sadhu, S., Maiti, T. K. (2013): Cellulase production by bacteria: a review. - British Microbiology Research Journal 3(3): 235-258.

[41] Samira, M., Mohammad, R., Gholamreza, G. (2011): Carboxymethyl-cellulase and filterpaperase activity of new strains isolated from Persian Gulf. - Microbiology Journal 1(1): 8-16.

[42] Sangkharak, K., Vangsirikul, P., Janthachat, S. (2011): Isolation of novel cellulase from agricultural soil and application for ethanol production. - International Journal of Advanced Biotechnology and Research 2: 230-239.

[43] Seo, J. K., Park, T. S., Kwon, I. H., Piao, M. Y., Lee, C. H., Ha, J. K. (2013): Characterization of cellulolytic and xylanolytic enzymes of Bacillus licheniformis JK7 isolated from the rumen of a native Korean goat. - Asian-Australasian Journal of Animal Sciences 26(1): 50-58.

[44] Shahid, Z. H., Irfan, M., Nadeem, M., Syed, Q., Qazi, J. I. (2016): Production, purification, and characterization of carboxymethyl cellulase from novel strain Bacillus megaterium. Environmental Progress \& Sustainable Energy 35(6): 1741-1749.

[45] Sharma, S., Yazdani, S. S. (2016): Diversity of Microbial Cellulase System. - In: Gupta, V. (ed.) New and Future Developments in Microbial Biotechnology and Bioengineering. Elsevier Inc., Amsterdam.

[46] Shobharani, P., Yogesh, D., Halami, P. M., Sachindra, N. M. (2013): Potential of cellulase from Bacillus megaterium for hydrolysis of Sargassum. - Journal of Aquatic Food Product Technology 22: 520-535.

[47] Soares-Júnior, F. L., Dias, A. C. F., Fasanella, C. C., Taketani, R. G., Lima, A. O. S., Melo, I. S., Andreote, F. D. (2013): Endo- and exoglucanase activities in bacteria from mangrove sediment. - Brazilian Journal of Microbiology 44(3): 969-976.

[48] Soby, S. D., Gadagkar, S. R., Contreras, C., Caruso, F. L. (2013): Chromobacterium vaccinii sp. nov., isolated from native and cultivated cranberry (Vaccinium macrocarpon Ait.) bogs and irrigation ponds. - International Journal of Systematic and Evolutionary Microbiology 63: 1840-1846.

[49] Sriariyanun, M., Tantayotai, P., Yasurin, P., Pornwongthong, P., Cheenkachorn, K. (2016): Production, purification and characterization of an ionic liquid tolerant cellulase from 
Bacillus sp. isolated from rice paddy field soil. - Electronic Journal of Biotechnology 19: 23-28.

[50] Sudiana, I. M., Rahayu, R. D., Imanuddin, H., Rahmansyah, M. (2001): Cellulolytic bacteria of soil of Gunung Halimun National Park. - Berita Biologi 5(6): 703-709.

[51] Vazquez-Arista, M., Smith, R. H., Olalde-Portugal, V., Hinojosa, R. E., HernandezDelgadillo, R., Blanco-Labra, A. (1997): Cellulolytic bacteria in the digestive system of Prostephanus truncatus (Coleoptera: Bostrichidae). - Journal of Economic Entomology 90(5): 1371-1376.

[52] Waghmare, P. R., Patil, S. M., Jadhav, S. L., Jeon, B. H., Govindwar, S. P. (2018): Utilization of agricultural waste biomass by cellulolytic isolate Enterobacter sp. SUK-Bio. - Agriculture and Natural Resources 52: 399-406.

[53] Wang, Z., Robertson, K. L., Liu, C., Liu, J. L., Johnson, B. J., Leary, D. H., Compton, J. R., Vuddhakul, V., Legler, P. M., Vora, G. J. (2015): A novel Vibrio beta-glucosidase (LamN) that hydrolyzes the algal storage polysaccharide laminarin. - FEMS Microbiology Ecology 91: 1-10. doi: 10.1093/femsec/fiv087.

[54] Wee, Y. J., Kim, S. Y., Yoon, S. D., Ryu, H. W. (2011): Isolation and characterization of a bacterial cellulose producing bacterium derived from the persimmon vinegar. - African Journal of Biotechnology 10(72): 16267-16276.

[55] Wu, L. S., Feng, S., Nie, Y. Y., Zhou, J. H., Yang, Z. R., Zhang, J. (2015): Soil cellulase activity and fungal community responses to wetland degradation in the Zoige Plateau, China. - Journal of Mountain Science 12(2): 471-482.

[56] Zhang, Y. H. P., Himmel, M. E., Mielenz, J. R. (2006): Outlook for cellulase improvement: Screening and selection strategies. - Biotechnology Advances 24: 452-481. 